\title{
Comparison of tropospheric gas-phase chemistry schemes for use within global models
}

\author{
K. M. Emmerson and M. J. Evans \\ School of Earth \& Environment, University of Leeds, Leeds, LS2 9JT, UK \\ Received: 24 September 2008 - Published in Atmos. Chem. Phys. Discuss.: 28 November 2008 \\ Revised: 27 February 2009 - Accepted: 2 March 2009 - Published: 12 March 2009
}

\begin{abstract}
Methane and ozone are two important climate gases with significant tropospheric chemistry. Within chemistry-climate and transport models this chemistry is simplified for computational expediency. We compare the state of the art Master Chemical Mechanism (MCM) with six tropospheric chemistry schemes (CRI-reduced, GEOSCHEM and a GEOS-CHEM adduct, MOZART-2, TOMCAT and CBM-IV) that could be used within composition transport models. We test the schemes within a box model framework under conditions derived from a composition transport model and from field observations from a regional scale pollution event. We find that CRI-reduced provides much skill in simulating the full chemistry, yet with greatly reduced complexity. We find significant variations between the other chemical schemes, and reach the following conclusions. 1) The inclusion of a gas phase $\mathrm{N}_{2} \mathrm{O}_{5}+\mathrm{H}_{2} \mathrm{O}$ reaction in one scheme and not others is a large source of uncertainty in the inorganic chemistry. 2) There are significant variations in the calculated concentration of PAN between the schemes, which will affect the long range transport of reactive nitrogen in global models. 3) The representation of isoprene chemistry differs hugely between the schemes, leading to significant uncertainties on the impact of isoprene on composition. 4) Differences are found in $\mathrm{NO}_{3}$ concentrations in the nighttime chemistry. Resolving these four issues through further investigative laboratory studies will reduce the uncertainties within the chemical schemes of global tropospheric models.
\end{abstract}

\section{Introduction}

Anthropogenically induced climate change is largely caused by the changing composition of the atmosphere. Over the last 100 years the concentrations of carbon dioxide $\left(\mathrm{CO}_{2}\right)$,

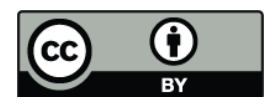

Correspondence to: K. M. Emmerson (k.emmerson@see.leeds.ac.uk) methane $\left(\mathrm{CH}_{4}\right)$ and ozone $\left(\mathrm{O}_{3}\right)$, have all increased significantly (IPCC, 2007). The associated radiative forcing is dominated by $\mathrm{CO}_{2}$, however $\mathrm{CH}_{4}$ and $\mathrm{O}_{3}$ also play a significant role. To understand these changes and to predict the future atmospheric composition, it is essential that we understand the photochemistry of the troposphere. Tropospheric photochemistry is dominated by a complex odd oxygen, hydrogen and nitrogen radical chemistry, coupled to the oxidation of volatile organic compounds (VOCs) (Logan et al., 1981). This presents various challenges. A complete and explicit representation of tropospheric chemistry is limited by our understanding of the concentrations of gas phase species (often at very low concentrations) and their associated reactions. Even with our limited knowledge, the state of the science representation requires many thousands of species and tens of thousands of reactions. In the past decade, research has concentrated on producing large, chemically explicit, reaction schemes. For example, Aumont et al. (2005) produced a scheme of 350000 species and 2 million reactions. The Master Chemical Mechanism (Jenkin et al., 2003; Saunders et al., 2003; Bloss et al., 2005) contains approximately 5600 species and 13500 reactions. Representing this level of chemical complexity within a global chemistryclimate model is beyond the computational resources currently available. Simplifications are required that retain the essential features of the chemistry whilst removing most of the complexity. Various methods have been used in the past in global models, with varying degrees of success. Simplifications involve reducing the number of VOCs considered and by lumping the carbon from the discarded species into representative surrogates.

In an earlier study, Derwent (1990) used 24 chemical schemes to compare modelled $\mathrm{O}_{3}$ concentrations observed at sites across Europe. He determined that the more explicit schemes were able to capture the peak concentrations in $\mathrm{O}_{3}$, peroxyacetylnitrate (PAN) and hydrogen peroxide $\left(\mathrm{H}_{2} \mathrm{O}_{2}\right)$ more often than the highly parameterized schemes. The

Published by Copernicus Publications on behalf of the European Geosciences Union. 
Table 1. The chemical mechanisms. Note that only tropospheric reactions are used in this study. Number of reactions required for the $(\mathrm{M})=$ full chemistry test and $(\mathrm{T})=\mathrm{TORCH}$ tests.

\begin{tabular}{|c|c|c|c|c|}
\hline & Reactions & No. of Species & Model Chemistry Includes... & Notes \\
\hline $\mathrm{MCM}$ & $\begin{array}{r}13500 \\
766(\mathrm{M}) \\
6502(\mathrm{~T})\end{array}$ & $\begin{array}{r}5600 \\
248(\mathrm{M}) \\
2241(\mathrm{~T})\end{array}$ & $\begin{array}{l}135 \text { VOCs including } 22 \text { alkanes } \leq \mathrm{C}_{12} \text {, } \\
16 \text { alkenes } \leq \mathrm{C}_{6}, 6 \text { aldehydes, } 18 \text { aromatics, } \\
\text { isoprene, } \alpha \text { - and } \beta \text {-pinene }\end{array}$ & $\begin{array}{l}\text { The benchmark } \\
\text { scheme }\end{array}$ \\
\hline CRI-reduced & 555 & 196 & $\begin{array}{l}23 \text { VOCs including alkanes } \leq \mathrm{C}_{4} \text {, alkenes } \leq \mathrm{C}_{4} \\
9 \text { oxygenated compounds, benzene, toluene, } \\
\text { o-xylene, isoprene, } \alpha \text { - and } \beta \text {-pinene }\end{array}$ & $\begin{array}{l}4 \% \text { of the size } \\
\text { of the MCM }\end{array}$ \\
\hline GEOSito & 490 & 179 & $\begin{array}{l}\text { alkanes } \leq \mathrm{C}_{8} \text {, alkenes } \leq \mathrm{C}_{4}, 11 \text { oxygenated } \\
\text { compounds, benzene, toluene, m-xylene, } \\
\text { isoprene, } \alpha \text { - and } \beta \text {-pinene }\end{array}$ & $\begin{array}{l}\text { Ito et al. (2007) } \\
\text { extended GEOS-CHEM } \\
\text { mechanism }\end{array}$ \\
\hline GEOS-CHEM & 273 & 93 & $\begin{array}{l}\text { alkanes } \leq \mathrm{C}_{3} \text {, alkenes } \leq \mathrm{C}_{4}, 9 \text { oxygenated } \\
\text { compounds, isoprene }\end{array}$ & \\
\hline MOZART-2 & 158 & 63 & $\begin{array}{l}\text { alkanes } \leq \mathrm{C}_{4} \text {, alkenes } \leq \mathrm{C}_{3} \text {, acetylene, } \\
\text { acetaldehyde, acetone, methanol, } \\
\text { isoprene and lumped monoterpenes }\end{array}$ & \\
\hline TOMCAT & 152 & 58 & $\begin{array}{l}\text { Ethane, propane, acetylene, acetaldehyde, } \\
\text { acetone, methanol and isoprene }\end{array}$ & $\begin{array}{l}\text { Includes Mainz Isoprene } \\
\text { Mechanism; Pöschl et al. (2000) }\end{array}$ \\
\hline CBM-IV & 85 & 47 & $\begin{array}{l}\text { Ethene, isoprene, lumped parafins, } \\
\text { olefins, aldehydes and aromatics }\end{array}$ & \\
\hline
\end{tabular}

"PhotoComp" group was set up to provide a model intercomparison for the Intergovernmental Panel on Climate Change, on modelling tropospheric $\mathrm{HO}_{\mathrm{x}}$ cycling and $\mathrm{O}_{3}$ production (Olsen et al., 1997). Box models from 21 research groups were run under a range of atmospheric conditions to investigate the differences in the gas phase photochemistry. No attempt was made to standardize complex and photolytic reaction rates. The source of resulting disparity in $\mathrm{O}_{3}$ concentrations was found to be mainly due to differences in the reaction rate of $\mathrm{O}_{3}$ with $\mathrm{HO}_{2}$. The problem was traced back to whether water dependence in the $\mathrm{HO}_{2}+\mathrm{HO}_{2} \rightarrow \mathrm{H}_{2} \mathrm{O}_{2}$ reaction was included, and differing photolysis between models.

In this paper, six small and "reduced" gas-phase schemes currently employed in composition transport models are compared to a "state of the science" explicit chemistry scheme. We do not consider heterogeneous reaction in our comparison. Heterogeneous chemistry is important for the composition of the atmosphere (Dentner et al., 1993; Evans and Jacob, 2005; etc.) however considering uncertainties in its representation in models is beyond this scope of this exercise. It should be noted that the simulations performer here will be impacted by the lack of heterogeneous chemistry, This is especially the case for $\mathrm{NO}_{\mathrm{x}}$ where the nighttime lifetime is likely to be longer than in reality. The aim is to evaluate the schemes under a range of different conditions and to identify areas of weakness.

\section{The chemistry schemes}

The MCM (version 3.1) is an explicit chemical scheme which degrades 135 primary VOCs into $\mathrm{CO}_{2}$ and $\mathrm{H}_{2} \mathrm{O}$. The MCM contains approximately 5600 species and 13500 reactions based on a predefined protocol (Jenkin et al., 2003; Saunders et al., 2003; Bloss et al., 2005). It was designed to provide regulatory controls on VOC emissions within the UK. The MCM has been tested against atmospheric measurements and smog chamber data (Jenkin and Hayman, 1999), and evaluated in urban (Emmerson et al., 2007, 2005), rural and marine modelling studies (Carslaw et al., 1999, 2001; Sommariva et al., 2004).

We use six smaller chemistry schemes in this study: CRI-reduced, GEOS-CHEM and a GEOS-CHEM extension, MOZART-2, TOMCAT and CBM-IV. We compare these to the explicit Master Chemical Mechanism (MCM). We note here that just because the MCM is classed as "state of the science" we are not assuming it is without limitations. Our scheme comparisons are therefore assumed to be relative to one another, rather than a comparison with "reality". The scheme sizes and capabilities are summarized in Table 1.

Based upon the MCM, the Common Representative Intermediates mechanism (CRI-mech) (Jenkin et al., 2002) is a reduction scheme based on the $\mathrm{O}_{3}$ production potential of a species. A lumping methodology assigns large numbers of MCM species to generic intermediate species, which are 
then used to channel the chemistry into smaller compounds such as formaldehyde (HCHO). These smaller species can then be treated using the MCM. The development of version 2 of CRI-mech, and a series of five reduced variants of the mechanism, has recently been reported (Jenkin et al., 2008; Watson et al., 2008). The most reduced variant (denoted "CRI v2-R5" in Watson et al., 2008) contains 196 species and 555 reactions, and is used in this work (denoted "CRIreduced"). CRI-reduced degrades 23 primary emitted VOCs including alkanes $\geq \mathrm{C}_{4}$, the aromatic compounds benzene, toluene and o-xylene, and biogenic compounds isoprene, $\alpha$ and $\beta$-pinene. Given its size there is potential to use the CRIreduced scheme within composition transport models in the future.

The GEOS-CHEM scheme (Bey et al., 2001; Evans and Jacob, 2005) with subsequent amendments outlined on the web (http://homepages.see.leeds.ac.uk/ lecmje/ GEOS-CHEM/GEOS-CHEM_Chemistry.htm) was developed for inclusion in a global atmospheric chemistrytransport model using the Goddard Earth Observation System meteorology. It has 273 reactions and considers the oxidation of methane, ethane, propane, an alkene (nominally propene), a higher alkane (nominally butane), and isoprene. Additional chemical complexity has been added to GEOSCHEM to account for higher alkanes $\geq \mathrm{C}_{4}$, biogenic species $(\alpha$-pinene and limonene) and aromatic compounds (benzene, toluene and m-xylene) by Ito et al. (2007). This 490 reactions scheme also includes an explicit representation of hydroxyl alkyl nitrates produced rapidly from isoprene oxidation. We test this enhanced GEOS-CHEM scheme separately and name it GEOSito.

MOZART-2 was developed by communities at NCAR in Colorado, the GFD Laboratory at Princeton and MPI at Hamburg (Horowitz et al., 2003). It has 158 reactions degrading alkanes $\leq \mathrm{C}_{4}$, alkenes $\leq \mathrm{C}_{3}$, 4 oxygenated compounds and isoprene. A lumped monoterpene compound has been included to add to the biogenic modelling capabilities.

The TOMCAT chemistry scheme (Chipperfield et al., 1993; Law et al., 1998; Stockwell and Chipperfield, 1999) contains 152 reactions and considers the oxidation of methane, ethane and propane. TOMCAT has been increased in recent years by the addition of the 34 reaction Mainz Isoprene Mechanism (Pöschl et al., 2000). There is no representation for higher hydrocarbons or aromatic chemistry.

The CBM-IV scheme (Gery et al., 1989) is the smallest scheme tested in this work with 85 reactions, and is used for air pollution regulation. It considers the oxidation of lumped paraffin and olefin species, such as toluene and xylene, and includes isoprene. The CBM-IV has been extended for use in global models (inclusion of methane oxidation and some additional inorganic reaction) and is used within the GISS model (Shindell et al., 2003) and Tracer Model 3 (Houweling et al., 1998) to study tropospheric chemical dynamics. The scheme used in this comparison is that of Houweling et al. (1998). It should be noted that other versions of the CBM-
IV exist which may be more suitable for inclusion in a global model (e.g. Zaveri and Peters, 1999) however they are not used in global chemistry models and are thus not considered here.

\section{The model framework}

Each chemistry scheme is removed from the parent model and translated into the Kinetic PreProcessor (KPP) format (Sandu and Sander, 2006), which writes the ordinary differential equations to be integrated (available from http:// people.cs.vt.edu/ asandu/Software/Kpp). The chemistry is integrated forwards using a Rosenbrock solver (Hairer and Wanner, 1991). Photolysis rates have been calculated using the solar zenith angle based on the framework used for the MCM (Jenkin, 1997; Saunders et al., 2003). Trimolecular reactions are represented differently within each model. For simplicity these reaction rates have been taken from published IUPAC data (IUPAC, 2001). In order to provide a consistent assessment, we have switched off all heterogeneous chemistry. This will tend to increase the lifetime of $\mathrm{NO}_{\mathrm{x}}$ in the simulations due to the removal of $\mathrm{N}_{2} \mathrm{O}_{5}$ hydrolysis which is a significant sink for $\mathrm{NO}_{\mathrm{x}}$ (Dentener et al., 1993) however as our objective is a consistent evaluation of the gas-phase schemes this is not a significant problem. TOMCAT includes a "gas phase" reaction of $\mathrm{N}_{2} \mathrm{O}_{5}+\mathrm{H}_{2} \mathrm{O}$ using the IUPAC recommendation for the reaction rate of $2.5 \times 10^{-22}$ molecule $\mathrm{cm}^{-3} \mathrm{~s}^{-1}$ (IUPAC, 2001). This reaction is discussed later.

\subsection{Boundary conditions}

The chemistry schemes are run within a single box, forward in time for $120 \mathrm{~h}$ (5 days) starting from midnight. The choice of timescale is complex. Very long simulations would be unrealistic as the mixing of air masses would become a significant driver of composition, whereas very short timescales would not test the ability of the chemistry to feedback significantly on itself. To fully evaluate all the appropriate timescales, a global model would have to be run for multiples of the methane lifetime (the longest lived species). This is beyond the numerical resources available and a compromise of 5 days is chosen. It should be noted that initializing the model at midnight may emphasise the importance of night time chemistry and this is discussed later in the paper.

The simplest assumption for a single box is to assume no external fluxes. This implies that no emissions, deposition nor mixing takes place. For some species this approximation leads to a significant deviation from reality over the 5 day integration. This is most notable for oxides of nitrogen where the rapid conversion of $\mathrm{NO}_{\mathrm{x}}$ (defined as $\mathrm{NO}+\mathrm{NO}_{2}$ ) to $\mathrm{NO}_{\mathrm{z}}$ (defined as all oxidized nitrogen species minus $\mathrm{NO}_{\mathrm{x}}$ ) can lead to unrealistic conditions. To counter this, we repeat simulations maintaining a constant 
concentration of $\mathrm{NO}_{\mathrm{x}}^{\text {tot }}$. We define $\mathrm{NO}_{\mathrm{x}}^{\text {tot }}$ as the sum of $[\mathrm{NO}]+\left[\mathrm{NO}_{2}\right]+\left[\mathrm{NO}_{3}\right]+2\left[\mathrm{~N}_{2} \mathrm{O}_{5}\right]+[\mathrm{HONO}]+\left[\mathrm{HO}_{2} \mathrm{NO}_{2}\right]$.

\subsection{The simulations}

The chemistry schemes should be capable of accurately simulating the chemistry of the atmosphere under the wide range of conditions found within the troposphere. Over the remote marine boundary layer, concentrations of anthropogenic pollutants are low, whereas over highly populated regions concentrations of pollutants are high; chemical processes are different in the warm tropics compared with the cold poles etc. The ideal reduced chemistry scheme should be able to simulate the chemistry under the range of conditions found through the troposphere.

We identify a reasonable and consistent range of concentrations based on the output of a composition transport model. However, the coarse resolution of the global model results in an underestimate of the maximum concentrations likely to occur in industrial regions during pollution events. In order to simulate a regional pollution event, concentrations are taken from a field program around London. Conditions from the global model and the London project are described below.

\subsection{Global model conditions}

An annual simulation (nominally the year 2004) of the GEOS-CHEM composition transport model (Bey et al., 2001 ) is used to prepare a range of appropriate initial conditions for the model simulations. The model is run at $4^{\circ} \times 5^{\circ}$ resolution with 30 vertical levels. The monthly mean concentration of tracers for each grid box is then used for a principal components analysis. This transforms the information known about each grid box from being in "concentration space" to being represented as a series of components which describe the variability between species. For example, in most industrial gridboxes the concentrations of primarily emitted species such as $\mathrm{CO}, \mathrm{NO}_{\mathrm{x}}$, and the hydrocarbons all vary with time in a similar manner, whereas the composition of forested grid-boxes with high emissions of isoprene and other biogenically emitted VOCs vary in a similar manner. The first three principal components describe $75 \%$ of the compositional variability within the model. The first component represents the variation between clean and polluted regions, the second component represents a warm area versus cold difference and the third component represents a biogenically active versus a biogenically inactive region. The two gridboxes which exhibit the most extreme behaviour (i.e. have the highest and lowest values of the component) from within each of these first three principal components are selected and their monthly mean concentrations used as the initial conditions for these model simulations. This will test the chemistry schemes under the extreme sets of conditions likely to be encountered. Success at these extremes is likely to (but given the non-linear nature of the chemistry not guaranteed to) mean success for all situations. Table 2 gives the locations of the grid boxes and the conditions used. The different latitudes and days of year contribute to different photolytic conditions calculated within the model.

\subsection{TORCH inputs and carbon lumping}

Due to the spatial resolution of the GEOS-CHEM model, even the most anthropogenically polluted airmasses are less polluted than are observed in reality during a regional pollution event. In order to test the model under conditions typical of very polluted airmasses, data are used from the Tropospheric Organic CHemistry (TORCH) field campaign which took place 25 miles north east of London, UK, during the summer of 2003, amidst a heat wave and photochemical smog episode (Lee et al., 2006). We have model inputs for 12 long-chain and cyclic alkanes $\leq \mathrm{C}_{8}, 11$ alkenes $\leq \mathrm{C}_{5}, 6$ aromatics $\leq \mathrm{C}_{8}, 3$ alcohols, isoprene and a range of small molecular weight aldehydes, acetylene and 1,3butadiene (see Table 3). The MCM is the only chemistry scheme used here equipped to model the TORCH observations explicitly. Therefore some lumping of the carbon has been undertaken on a per carbon molecule basis to fit the other schemes, ensuring that the total initial concentration of reactive carbon ( $\mathrm{ppbC}$ ) in all the schemes is the same.

Table 3 shows the input concentrations for the average TORCH conditions along with the lumping taking place within the different schemes. Where schemes enable explicit representation, this is carried out. For all species which are not represented within a particular scheme, all alkanes are lumped into the highest alkane, all alkenes into the highest alkene, and all aromatics into the highest aromatic, maintaining the total mass of carbon. Other approaches could have been taken (mapping by functional group, $\mathrm{OH}$ reactivity etc.) however all of these suffer from being one approximation or another. The approach taken here is clear and simple, however, the mapping of VOCs from a total emitted to chemistry scheme specific VOCs is non-trivial and plays an important role in determining the differences between models. A full investigation of its significance should be considered in the future. There are some exceptions, for example there is no alkene or aromatic representation in TOMCAT. Therefore, all alkenes and aromatics are lumped into propane on a per carbon basis (isoprene is treated separately). The MOZART2 scheme allows all alkane carbon into butane, but no aromatic representation means the aromatic carbon is lumped into propene. The CRI-reduced scheme allows for benzene, toluene, xylene, all alkanes and alkenes $\leq \mathrm{C}_{4}$ to be treated explicitly; therefore all higher molecular weight compounds have been placed into butane or trans-but-2-ene where appropriate. For the GEOS-CHEM and GEOSito schemes the ethane, propane and isoprene concentrations are again taken from the observations, the ALK4 species is used to represent the remaining alkanes and the PRPE species is used to 
Table 2. Input values (ppb, except $\mathrm{H}_{2} \mathrm{O}$ which is $\times 10^{17}$ molecule $\mathrm{cm}^{-3}$ ), from the principal component analysis. $\mathrm{CH}_{3} \mathrm{COCH}_{3}$ has been incorporated into the OLE species in the CBM-IV mechanism.

\begin{tabular}{lrrrrrr}
\hline & Industrial & Clean & Cold, Dry & Hot, Wet & Biogenic & Non-biogenic \\
\hline Lon $\left({ }^{\circ} \mathrm{E}\right)$ & 100 & -120 & -5 & -140 & -145 & -160 \\
Lat $\left({ }^{\circ} \mathrm{N}\right)$ & 18 & -30 & -6 & -10 & 26 & -75 \\
Julian Day No. & 105 & 45 & 285 & 345 & 195 & 365 \\
Pressure $(\mathrm{hPa})$ & 982.6 & 941.6 & 136.6 & 982.6 & 982.6 & 136.6 \\
Temp $(\mathrm{K})$ & 299.7 & 299.4 & 214.4 & 302.7 & 302.5 & 214.3 \\
$\mathrm{H}_{2} \mathrm{O}$ & 3.9 & 5.7 & 0.01 & 6.8 & 5.3 & 0.01 \\
$\mathrm{CH}_{4}$ & 1700.0 & 1700.0 & 1700.0 & 1700.0 & 1700.0 & 1700.0 \\
$\mathrm{CO}$ & 956.5 & 58.4 & 87.6 & 56.9 & 217.7 & 56.1 \\
$\mathrm{NO}_{2}$ & 3.6 & 0.003 & 0.58 & 0.002 & 0.12 & 0.14 \\
$\mathrm{O}_{3}$ & 63.3 & 19.0 & 86.3 & 13.3 & 10.5 & 93.9 \\
$\mathrm{H}_{2} \mathrm{O}_{2}$ & 11.0 & 1.7 & 0.05 & 1.5 & 8.5 & 0.02 \\
$\mathrm{HNO}_{3}$ & 2.8 & 0.07 & 0.5 & 0.04 & 0.2 & 0.2 \\
$\mathrm{C}_{2} \mathrm{H}_{6}$ & 5.6 & 0.2 & 0.9 & 0.2 & 0.6 & 0.3 \\
$\mathrm{C}_{3} \mathrm{H}_{8}$ & 1.4 & 0.003 & 0.2 & 0.002 & 0.09 & 0.02 \\
$\mathrm{C}_{5} \mathrm{H}_{8}$ & 0.3 & - & - & - & 6.7 & - \\
$\mathrm{HCHO}$ & 6.0 & 0.4 & 0.06 & 0.4 & 4.8 & 0.02 \\
$\mathrm{CH}_{3} \mathrm{CHO}$ & 3.0 & 0.004 & 0.007 & 0.004 & 3.8 & 0.0006 \\
$\mathrm{CH}_{3} \mathrm{COCH}$ & 17.9 & 1.5 & 2.0 & 1.5 & 15.4 & 0.36 \\
$\mathrm{PAN}$ & 1.0 & 0.00008 & 0.2 & 0.0003 & 0.04 & 0.03 \\
\hline
\end{tabular}

represent the remaining alkenes, alkynes and aromatics. In addition, the GEOSito scheme can deal separately with benzene and toluene. The CBM-IV mechanism allows ethane, propane, isoprene, toluene and xylene degradation, leaving the higher alkanes lumped into the PAR species, and the higher alkenes into the OLE species. Benzene has been lumped into the toluene species.

\section{Diagnostics}

The focus of this study is on chemistry schemes relevant for chemistry-climate simulations. Thus the emphasis is upon $\mathrm{CH}_{4}$ and $\mathrm{O}_{3}$. The long lifetime of $\mathrm{CH}_{4}$ ( $\sim 10$ years) relative to the length of the simulations (5 days) makes a direct comparison of $\mathrm{CH}_{4}$ less useful. The dominant sink for $\mathrm{CH}_{4}$ in the atmosphere is the reaction of $\mathrm{OH}$, thus we focus the comparison on the ability of the chemistry schemes to simulate $\mathrm{OH}$. Ozone is another potent climate gas and also contributes to the oxidizing capacity of the atmosphere through production of the hydroxyl radical, $\mathrm{OH}$. At ground level, $\mathrm{O}_{3}$ also causes public health issues and leads to the destruction of plant material. Reactive nitrogen species $\left(\mathrm{NO}_{\mathrm{x}}\right)$ play a central role in the chemistry of the troposphere. They are responsible for the catalytic production of $\mathrm{O}_{3}$ and for the conversion of $\mathrm{HO}_{2}$ to $\mathrm{OH}$. Numerical models must have some skill in simulating the $\mathrm{NO}_{\mathrm{x}}$ concentrations. In remote regions the source of $\mathrm{NO}_{\mathrm{x}}$ is the decomposition of PAN which is formed in polluted regions from the oxidation of hydrocarbons in the presence of $\mathrm{NO}_{\mathrm{x}}$ and subsequently exported to remote regions. During the night $\mathrm{NO}_{3}$ acts as the dominant oxidant and needs to be considered. In this work we focus our comparisons on the ability of the various chemistry schemes on simulating the $\mathrm{OH}, \mathrm{O}_{3}, \mathrm{NO}_{\mathrm{x}}, \mathrm{NO}_{3}$ and PAN concentrations.

Each of the chemistry schemes can be split into an "inorganic scheme" which considers essentially $\mathrm{O}_{\mathrm{x}}-\mathrm{HO}_{\mathrm{x}}-\mathrm{NO}_{\mathrm{x}}-$ $\mathrm{CO}-\mathrm{CH}_{4}$ chemistry, and an "organic" scheme that considers the degradation of VOCs. We test the inorganic chemistry first on the belief that there should be little model variability between the schemes. We then test the full chemistry schemes.

\section{Results}

We first present the results using the six initial conditions derived from the principal components analysis of the GEOSCHEM model. First the inorganic segments of the different chemistry schemes are tested without the inclusion of the $\mathrm{NO}_{\mathrm{x}}^{\text {tot }}$ case, then the full chemistry schemes are tested with the $\mathrm{NO}_{\mathrm{x}}^{\text {tot }}$ case and finally the full chemistry schemes are tested with the constant $\mathrm{NO}_{\mathrm{x}}^{\text {tot }}$ case. We tabulate the results in Table 4, to aid the reader in scheme comparisons with the MCM for $\mathrm{O}_{3}$ production capabilities.

\subsection{Inorganic schemes}

This section compares the results when only the models' inorganic schemes are used. Other than $\mathrm{CH}_{4}, \mathrm{HCHO}$ and $\mathrm{CH}_{3} \mathrm{OOH}$ there is no reactive carbon in any of these initial 
Table 3. Division of species into lumped compounds within the full chemistry scheme tests. TORCH input concentrations, ppb, except $\mathrm{H}_{2} \mathrm{O}$ in units $\times 10^{17}$ molecule $\mathrm{cm}^{-3}$. "Me" is a methyl group. Chemical species are named using the methodology adopted by each mechanism.

\begin{tabular}{|c|c|c|c|c|c|c|c|}
\hline $\mathrm{MCM}$ & AVE & CRI-reduced & GEOSito & GEOS-CHEM & MOZART-2 & TOMCAT & CBM-IV \\
\hline $\mathrm{H}_{2} \mathrm{O}$ & 3.69 & $\mathrm{H}_{2} \mathrm{O}$ & $\mathrm{H}_{2} \mathrm{O}$ & $\mathrm{H}_{2} \mathrm{O}$ & $\mathrm{H}_{2} \mathrm{O}$ & $\mathrm{H}_{2} \mathrm{O}$ & $\mathrm{H}_{2} \mathrm{O}$ \\
\hline $\mathrm{CO}$ & 20.30 & $\mathrm{CO}$ & $\mathrm{CO}$ & $\mathrm{CO}$ & $\mathrm{CO}$ & $\mathrm{CO}$ & $\mathrm{CO}$ \\
\hline NO & 2.83 & NO & NO & NO & $\mathrm{NO}$ & NO & $\mathrm{NO}$ \\
\hline $\mathrm{NO}_{2}$ & 10.50 & $\mathrm{NO}_{2}$ & $\mathrm{NO}_{2}$ & $\mathrm{NO}_{2}$ & $\mathrm{NO}_{2}$ & $\mathrm{NO}_{2}$ & $\mathrm{NO}_{2}$ \\
\hline PAN & 0.24 & PAN & PAN & PAN & PAN & PAN & PAN \\
\hline $\mathrm{O}_{3}$ & 34.30 & $\mathrm{O}_{3}$ & $\mathrm{O}_{3}$ & $\mathrm{O}_{3}$ & $\mathrm{O}_{3}$ & $\mathrm{O}_{3}$ & $\mathrm{O}_{3}$ \\
\hline $\mathrm{C}_{2} \mathrm{H}_{6}$ & 2.36 & $\mathrm{C}_{2} \mathrm{H}_{6}$ & $\mathrm{C}_{2} \mathrm{H}_{6}$ & $\mathrm{C}_{2} \mathrm{H}_{6}$ & $\mathrm{C}_{2} \mathrm{H}_{6}$ & $\mathrm{C}_{2} \mathrm{H}_{6}$ & PAR \\
\hline $\mathrm{C}_{2} \mathrm{H}_{4}$ & 0.57 & $\mathrm{C}_{2} \mathrm{H}_{4}$ & ETHE & PRPE & $\mathrm{C}_{2} \mathrm{H}_{6}$ & $\mathrm{C}_{2} \mathrm{H}_{6}$ & ETH \\
\hline $\mathrm{C}_{3} \mathrm{H}_{8}$ & 1.23 & $\mathrm{C}_{3} \mathrm{H}_{8}$ & $\mathrm{C}_{3} \mathrm{H}_{8}$ & $\mathrm{C}_{3} \mathrm{H}_{8}$ & $\mathrm{C}_{3} \mathrm{H}_{8}$ & $\mathrm{C}_{3} \mathrm{H}_{8}$ & PAR \\
\hline $\mathrm{C}_{3} \mathrm{H}_{6}$ & 0.18 & $\mathrm{C}_{3} \mathrm{H}_{6}$ & PRPE & PRPE & $\mathrm{C}_{3} \mathrm{H}_{6}$ & $\mathrm{C}_{3} \mathrm{H}_{8}$ & OLE \\
\hline $\mathrm{IC}_{4} \mathrm{H}_{10}$ & 0.34 & $\mathrm{NC}_{4} \mathrm{H}_{10}$ & ALK4 & ALK4 & $\mathrm{C}_{4} \mathrm{H}_{10}$ & $\mathrm{C}_{3} \mathrm{H}_{8}$ & PAR \\
\hline $\mathrm{NC}_{4} \mathrm{H}_{10}$ & 0.64 & $\mathrm{NC}_{4} \mathrm{H}_{10}$ & ALK4 & ALK4 & $\mathrm{C}_{4} \mathrm{H}_{10}$ & $\mathrm{C}_{3} \mathrm{H}_{8}$ & PAR \\
\hline $\mathrm{C}_{2} \mathrm{H}_{2}$ & 0.46 & $\mathrm{C}_{2} \mathrm{H}_{2}$ & ETHE & PRPE & $\mathrm{C}_{2} \mathrm{H}_{6}$ & $\mathrm{C}_{2} \mathrm{H}_{2}$ & OLE \\
\hline t-but-2-ene & 0.01 & t-but-2-ene & BUTE & PRPE & $\mathrm{C}_{3} \mathrm{H}_{6}$ & $\mathrm{C}_{3} \mathrm{H}_{8}$ & OLE \\
\hline But-1-ene & 0.04 & t-but-2-ene & PRPE & PRPE & $\mathrm{C}_{3} \mathrm{H}_{6}$ & $\mathrm{C}_{3} \mathrm{H}_{8}$ & OLE \\
\hline Me-propene & 0.04 & t-but-2-ene & PRPE & PRPE & $\mathrm{C}_{3} \mathrm{H}_{6}$ & $\mathrm{C}_{3} \mathrm{H}_{8}$ & OLE \\
\hline c-but-2-ene & 0.01 & t-but-2-ene & PRPE & PRPE & $\mathrm{C}_{3} \mathrm{H}_{6}$ & $\mathrm{C}_{3} \mathrm{H}_{8}$ & OLE \\
\hline $\mathrm{C}_{5} \mathrm{H}_{12}$ & 0.30 & $\mathrm{NC}_{4} \mathrm{H}_{10}$ & ALK4 & ALK4 & $\mathrm{C}_{4} \mathrm{H}_{10}$ & $\mathrm{C}_{3} \mathrm{H}_{8}$ & PAR \\
\hline $\mathrm{C}_{4} \mathrm{H}_{6}$ & 0.02 & t-but-2-ene & PRPE & PRPE & $\mathrm{C}_{3} \mathrm{H}_{6}$ & $\mathrm{C}_{3} \mathrm{H}_{8}$ & OLE \\
\hline t-pent-2-ene & 0.01 & t-but-2-ene & PRPE & PRPE & $\mathrm{C}_{3} \mathrm{H}_{6}$ & $\mathrm{C}_{3} \mathrm{H}_{8}$ & OLE \\
\hline pent-1-ene & 0.01 & t-but-2-ene & PRPE & PRPE & $\mathrm{C}_{3} \mathrm{H}_{6}$ & $\mathrm{C}_{3} \mathrm{H}_{8}$ & OLE \\
\hline Me-2-but-1-ene & 0.02 & t-but-2-ene & PRPE & PRPE & $\mathrm{C}_{3} \mathrm{H}_{6}$ & $\mathrm{C}_{3} \mathrm{H}_{8}$ & OLE \\
\hline Me-2-but-2-ene & 0.01 & t-but-2-ene & PRPE & PRPE & $\mathrm{C}_{3} \mathrm{H}_{6}$ & $\mathrm{C}_{3} \mathrm{H}_{8}$ & OLE \\
\hline c-pent-2-ene & 0.01 & t-but-2-ene & PRPE & PRPE & $\mathrm{C}_{3} \mathrm{H}_{6}$ & $\mathrm{C}_{3} \mathrm{H}_{8}$ & OLE \\
\hline di-Me-butane & 0.10 & $\mathrm{NC}_{4} \mathrm{H}_{10}$ & ALK4 & ALK4 & $\mathrm{C}_{4} \mathrm{H}_{10}$ & $\mathrm{C}_{3} \mathrm{H}_{8}$ & PAR \\
\hline c-hexane & 0.03 & $\mathrm{NC}_{4} \mathrm{H}_{10}$ & ALK7 & ALK4 & $\mathrm{C}_{4} \mathrm{H}_{10}$ & $\mathrm{C}_{3} \mathrm{H}_{8}$ & PAR \\
\hline Me-2-pentene & 0.11 & t-but-2-ene & ALK7 & PRPE & $\mathrm{C}_{3} \mathrm{H}_{6}$ & $\mathrm{C}_{3} \mathrm{H}_{8}$ & OLE \\
\hline Me-3-pentene & 0.11 & t-but-2-ene & ALK7 & PRPE & $\mathrm{C}_{3} \mathrm{H}_{6}$ & $\mathrm{C}_{3} \mathrm{H}_{8}$ & OLE \\
\hline $\mathrm{C}_{6} \mathrm{H}_{14}$ & 0.06 & $\mathrm{NC}_{4} \mathrm{H}_{10}$ & ALK7 & ALK4 & $\mathrm{C}_{4} \mathrm{H}_{10}$ & $\mathrm{C}_{3} \mathrm{H}_{8}$ & PAR \\
\hline $\mathrm{C}_{5} \mathrm{H}_{8}$ & 0.12 & $\mathrm{C}_{5} \mathrm{H}_{8}$ & ISOP & ISOP & $\mathrm{C}_{5} \mathrm{H}_{8}$ & $\mathrm{C}_{5} \mathrm{H}_{8}$ & ISOP \\
\hline $\mathrm{C}_{7} \mathrm{H}_{16}$ & 0.03 & $\mathrm{NC}_{4} \mathrm{H}_{10}$ & ALK7 & ALK4 & $\mathrm{C}_{4} \mathrm{H}_{10}$ & $\mathrm{C}_{3} \mathrm{H}_{8}$ & PAR \\
\hline $\mathrm{C}_{6} \mathrm{H}_{6}$ & 0.19 & $\mathrm{C}_{6} \mathrm{H}_{6}$ & BENZ & PRPE & $\mathrm{C}_{3} \mathrm{H}_{6}$ & $\mathrm{C}_{3} \mathrm{H}_{8}$ & TOL \\
\hline $\mathrm{C}_{8} \mathrm{H}_{18}$ & 0.04 & $\mathrm{NC}_{4} \mathrm{H}_{10}$ & ALK7 & ALK4 & $\mathrm{C}_{4} \mathrm{H}_{10}$ & $\mathrm{C}_{3} \mathrm{H}_{8}$ & PAR \\
\hline $\mathrm{C}_{7} \mathrm{H}_{8}$ & 0.34 & $\mathrm{C}_{7} \mathrm{H}_{8}$ & TOLU & PRPE & $\mathrm{C}_{3} \mathrm{H}_{6}$ & $\mathrm{C}_{3} \mathrm{H}_{8}$ & TOL \\
\hline Ethylbenzene & 0.06 & o-xylene & XYLE & PRPE & $\mathrm{C}_{3} \mathrm{H}_{6}$ & $\mathrm{C}_{3} \mathrm{H}_{8}$ & XYL \\
\hline m-xylene & 0.07 & o-xylene & XYLE & PRPE & $\mathrm{C}_{3} \mathrm{H}_{6}$ & $\mathrm{C}_{3} \mathrm{H}_{8}$ & XYL \\
\hline p-xylene & 0.07 & o-xylene & XYLE & PRPE & $\mathrm{C}_{3} \mathrm{H}_{6}$ & $\mathrm{C}_{3} \mathrm{H}_{8}$ & XYL \\
\hline o-xylene & 0.05 & o-xylene & XYLE & PRPE & $\mathrm{C}_{3} \mathrm{H}_{6}$ & $\mathrm{C}_{3} \mathrm{H}_{8}$ & XYL \\
\hline $\mathrm{CH}_{3} \mathrm{CHO}$ & 2.24 & $\mathrm{CH}_{3} \mathrm{CHO}$ & ALD2 & ALD2 & $\mathrm{MeCHO}$ & $\mathrm{MeCHO}$ & ALD2 \\
\hline $\mathrm{CH}_{3} \mathrm{OH}$ & 1.34 & $\mathrm{CH}_{3} \mathrm{OH}$ & $\mathrm{MOH}$ & $\mathrm{MOH}$ & $\mathrm{MeOH}$ & $\mathrm{MeOH}$ & OLE \\
\hline $\mathrm{CH}_{3} \mathrm{COCH}_{3}$ & 1.68 & $\mathrm{CH}_{3} \mathrm{COCH}_{3}$ & ACET & ACET & $\mathrm{Me} 2 \mathrm{CO}$ & $\mathrm{Me} 2 \mathrm{CO}$ & OLE \\
\hline MACR & 0.03 & t-but-2-ene & MACR & MACR & MACR & MACR & OLE \\
\hline $\mathrm{C}_{2} \mathrm{H}_{5} \mathrm{OH}$ & 1.11 & $\mathrm{C}_{2} \mathrm{H}_{5} \mathrm{OH}$ & $\mathrm{EOH}$ & $\mathrm{EOH}$ & $\mathrm{C}_{3} \mathrm{H}_{8}$ & $\mathrm{C}_{3} \mathrm{H}_{8}$ & OLE \\
\hline npropanol & 0.09 & $\mathrm{C}_{2} \mathrm{H}_{5} \mathrm{OH}$ & $\mathrm{ROH}$ & $\mathrm{ROH}$ & $\mathrm{C}_{3} \mathrm{H}_{8}$ & $\mathrm{C}_{3} \mathrm{H}_{8}$ & OLE \\
\hline $\mathrm{HCHO}$ & 1.63 & $\mathrm{HCHO}$ & $\mathrm{CH} 2 \mathrm{O}$ & $\mathrm{CH} 2 \mathrm{O}$ & $\mathrm{HCHO}$ & $\mathrm{HCHO}$ & FORM \\
\hline
\end{tabular}

conditions. Initially, comparisons highlighted a significant difference between TOMCAT and the other schemes. This is diagnosed as being due to the gas phase reaction of $\mathrm{N}_{2} \mathrm{O}_{5}+\mathrm{H}_{2} \mathrm{O}$ that is included in TOMCAT and not the others. Figure 1 shows that the inclusion of the reaction in TOMCAT leads to a $\sim 6 \mathrm{ppb}$ difference in $\mathrm{O}_{3}$ over the $120 \mathrm{~h}$ for the industrial case, impacting on $\mathrm{OH}$ production and $\mathrm{NO}_{\mathrm{x}}$ cycling. When this reaction is removed, we find much better agreement between the schemes (see Fig. 2). Although this reaction is in both the JPL and IUPAC recommendations there 
Table 4. $\mathrm{MCM} \mathrm{O}_{3}$ concentrations (ppb) after $120 \mathrm{~h}$ box model runs, with the corresponding results from all other schemes displayed as $+/-$ ppb. $\mathrm{NB}=$ without $\mathrm{NO}_{\mathrm{x}}^{\text {tot }}$. WB=with $\mathrm{NO}_{\mathrm{x}}^{\text {tot }} . \mathrm{T}=\mathrm{TORCH}$.

\begin{tabular}{|c|c|c|c|c|c|c|c|c|}
\hline \multicolumn{2}{|c|}{$\begin{array}{l}\text { Test and } \\
\text { corresponding } \\
\text { figure no. }\end{array}$} & MCM & $\begin{array}{r}\text { CRI- } \\
\text { reduced }\end{array}$ & GEOSito & GEOSCHEM & MOZART-2 & TOMCAT & $\begin{array}{r}\text { CBM- } \\
\text { IV }\end{array}$ \\
\hline \multirow{6}{*}{ 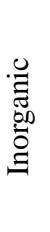 } & 2a. indus & 81.32 & -0.04 & -1.76 & -7.03 & -3.55 & -1.02 & -8.33 \\
\hline & 2b. clean & 10.35 & 0.00 & 0.05 & -0.62 & -0.59 & -0.16 & -0.20 \\
\hline & 2c. cold & 86.62 & 0.06 & 0.12 & 0.09 & 0.20 & 0.09 & 0.03 \\
\hline & 2d. hot & 7.36 & 0.00 & 0.05 & -0.42 & -0.41 & -0.12 & -0.11 \\
\hline & 2e. bio & 14.44 & 0.00 & -0.12 & -0.85 & -0.61 & -0.49 & -0.54 \\
\hline & 2f. n-bio & 93.76 & 0.35 & 0.38 & 0.32 & 0.41 & 0.38 & 0.29 \\
\hline \multirow{6}{*}{ 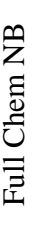 } & 3a. indus & 89.98 & -0.98 & -3.23 & -9.76 & -4.70 & -1.43 & -12.50 \\
\hline & 3b. clean & 10.35 & 0.00 & 0.07 & -0.61 & -0.57 & -0.11 & -0.41 \\
\hline & 3c. cold & 86.73 & 0.09 & 0.12 & 0.12 & 0.20 & 0.12 & 0.09 \\
\hline & 3d. hot & 7.35 & 0.00 & 0.05 & -0.42 & -0.41 & -0.11 & -0.30 \\
\hline & 3e. bio & 19.41 & -1.28 & -13.70 & -5.28 & 0.04 & -1.93 & -14.07 \\
\hline & 3f. n-bio & 93.76 & 0.35 & 0.38 & 0.32 & 0.41 & 0.38 & 0.29 \\
\hline \multirow{6}{*}{ 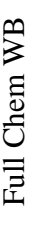 } & 4a. indus & 235.39 & 0.00 & -3.55 & -31.41 & 0.78 & -2.78 & -12.21 \\
\hline & 4b. clean & 70.54 & -0.29 & 2.49 & -3.67 & 15.14 & 2.86 & -3.26 \\
\hline & 4c. cold & 87.09 & -0.29 & -0.26 & -0.29 & -0.18 & -0.26 & -0.29 \\
\hline & 4d. hot & 42.37 & -0.17 & 1.57 & -1.56 & 15.02 & 1.03 & -0.25 \\
\hline & 4e. bio & 177.79 & -0.62 & -18.30 & -35.33 & 19.79 & -8.57 & -34.71 \\
\hline & 4f. n-bio & 94.11 & 0.03 & 0.06 & -0.03 & 0.06 & 0.03 & -0.03 \\
\hline \multirow{2}{*}{$\begin{array}{l}\bar{I} \\
U \\
0 \\
0 \\
\end{array}$} & 5b. NB & 67.39 & 0.12 & 17.60 & 2.53 & 10.74 & 12.25 & -17.56 \\
\hline & 5c. WB & 27.59 & -0.65 & 10.12 & -9.93 & 8.14 & 3.57 & -6.01 \\
\hline
\end{tabular}
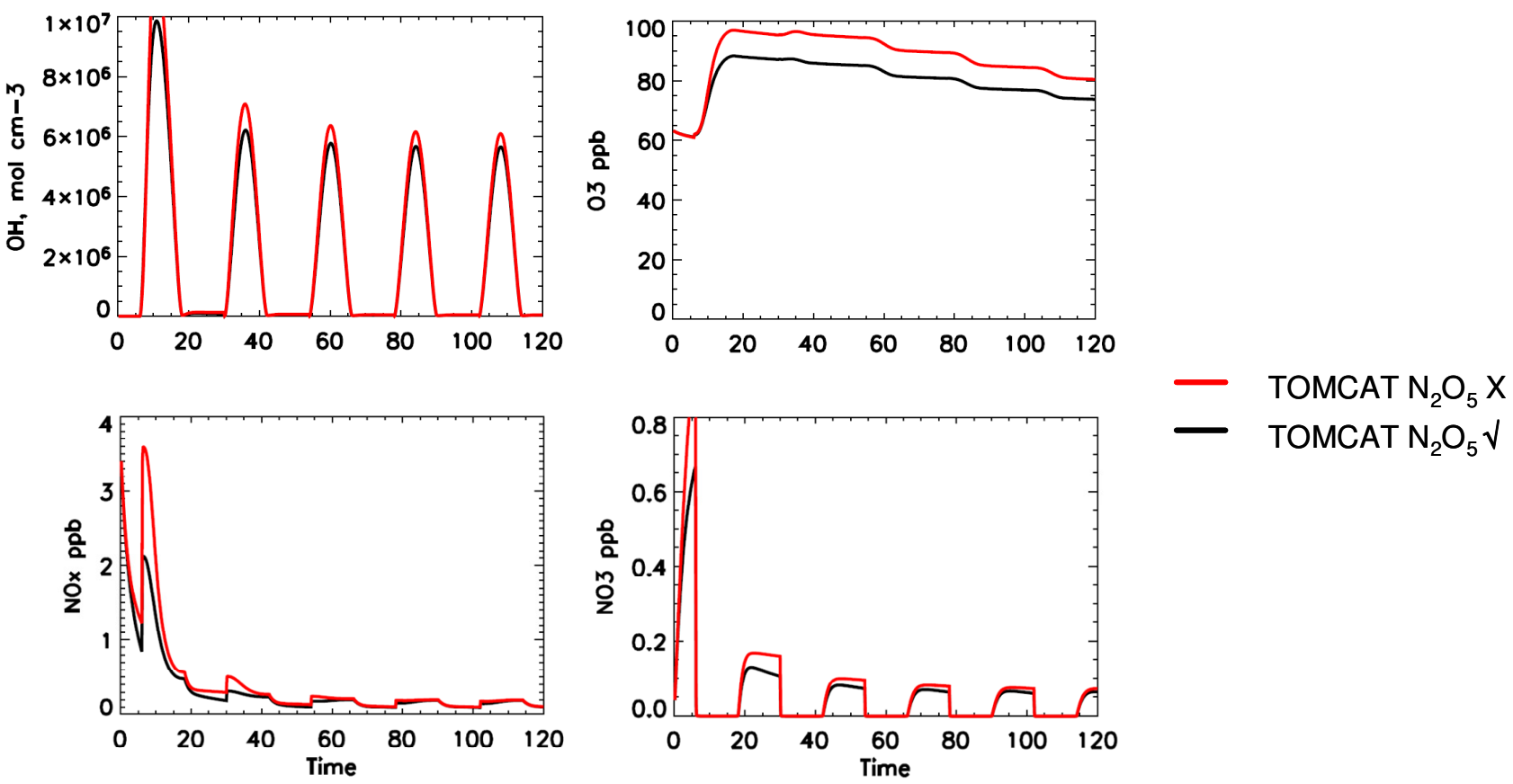

Fig. 1. Inorganic scheme $120 \mathrm{~h}$ run to show differences in $\mathrm{OH}, \mathrm{O}_{3}, \mathrm{NO}_{\mathrm{x}}$ and $\mathrm{NO}_{3}$ in $\mathrm{TOMCAT}$ with the gas phase $\mathrm{N}_{2} \mathrm{O}_{5}+\mathrm{H}_{2} \mathrm{O}$ reaction switched on $(\checkmark)$ and off (X). Initial conditions for the industrial scenario are used (Table 2). 

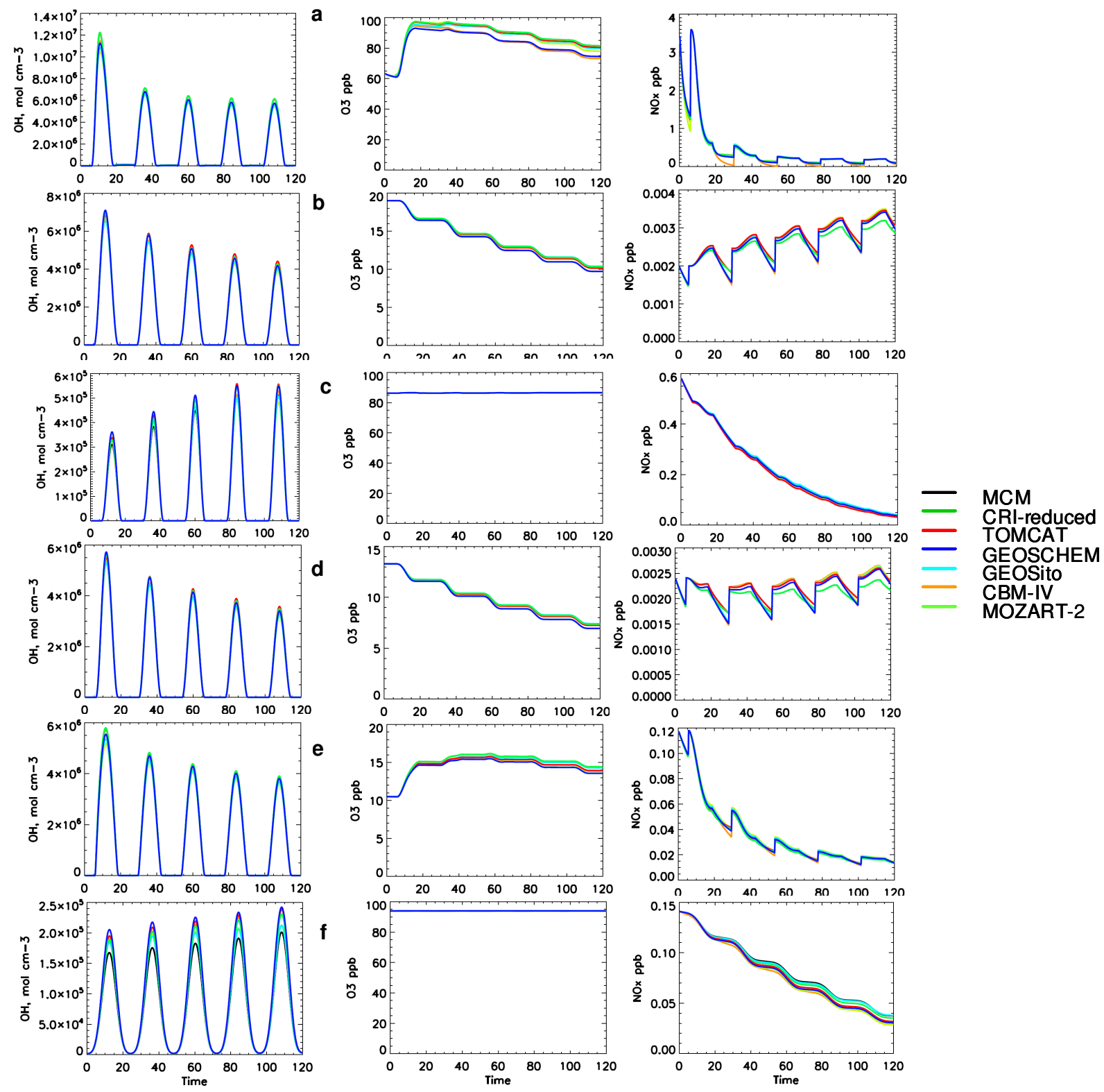

Fig. 2. Inorganic $120 \mathrm{~h}$ run without $\mathrm{NO}_{\mathrm{x}}^{\text {tot }}$ for $\mathrm{OH}$ (left), $\mathrm{O}_{3}$ (middle) and $\mathrm{NO}_{\mathrm{x}}=\mathrm{NO}+\mathrm{NO}_{2}$ (right). (a)=industrial, $(\mathbf{b})=$ clean, $(\mathbf{c})=$ cold \&dry, (d)=hot\&wet, (e)=biogenic, $(\mathbf{f})=$ non-biogenic.

is some obvious doubt in the community over the rate, and this should be investigated by further collaboration. We remove this reaction from the TOMCAT scheme in subsequent simulations.

Figure 2 shows results for all the chemistry schemes, showing $\mathrm{OH}, \mathrm{O}_{3}$ and $\mathrm{NO}_{\mathrm{x}}$ concentrations over 5 days. In general the results are similar, however given our assumed knowledge on the state of the science with regard to the inorganic chemistry it is surprising that the models exhibit any significant differences. The CBM-IV and GEOSCHEM models show significant deviations from the MCM run (our defined standard) in the industrial case (Fig. 2a). After 5 days we find differences in $\mathrm{O}_{3}$ of up to $\sim 8 \mathrm{ppb}$ between the schemes. Using the industrial temperature of 299.7 K we calculate the differences in the scheme rates compared to the MCM: for example in the CBM-IV mechanism $\mathrm{O}_{3}+\mathrm{OH}(-65 \%), \mathrm{NO}_{3}+\mathrm{NO}_{2}(-39 \%)$ and $\mathrm{O}_{3}+\mathrm{HO}_{2}(+29 \%)$; In GEOS-CHEM $\mathrm{O}_{3}+\mathrm{NO}(+14 \%)$. Much of this disagreement lies within differences between the IUPAC and JPL kinetics and reflect the uncertainties on the rate constants from laboratory studies (Gao et al., 1996) rather than any significant difference in the inorganic chemistry scheme. Although these uncertainties cannot be removed, a consistent set of reaction rates from the IUPAC and JPL kinetic data communities would remove one source of difference between models. 

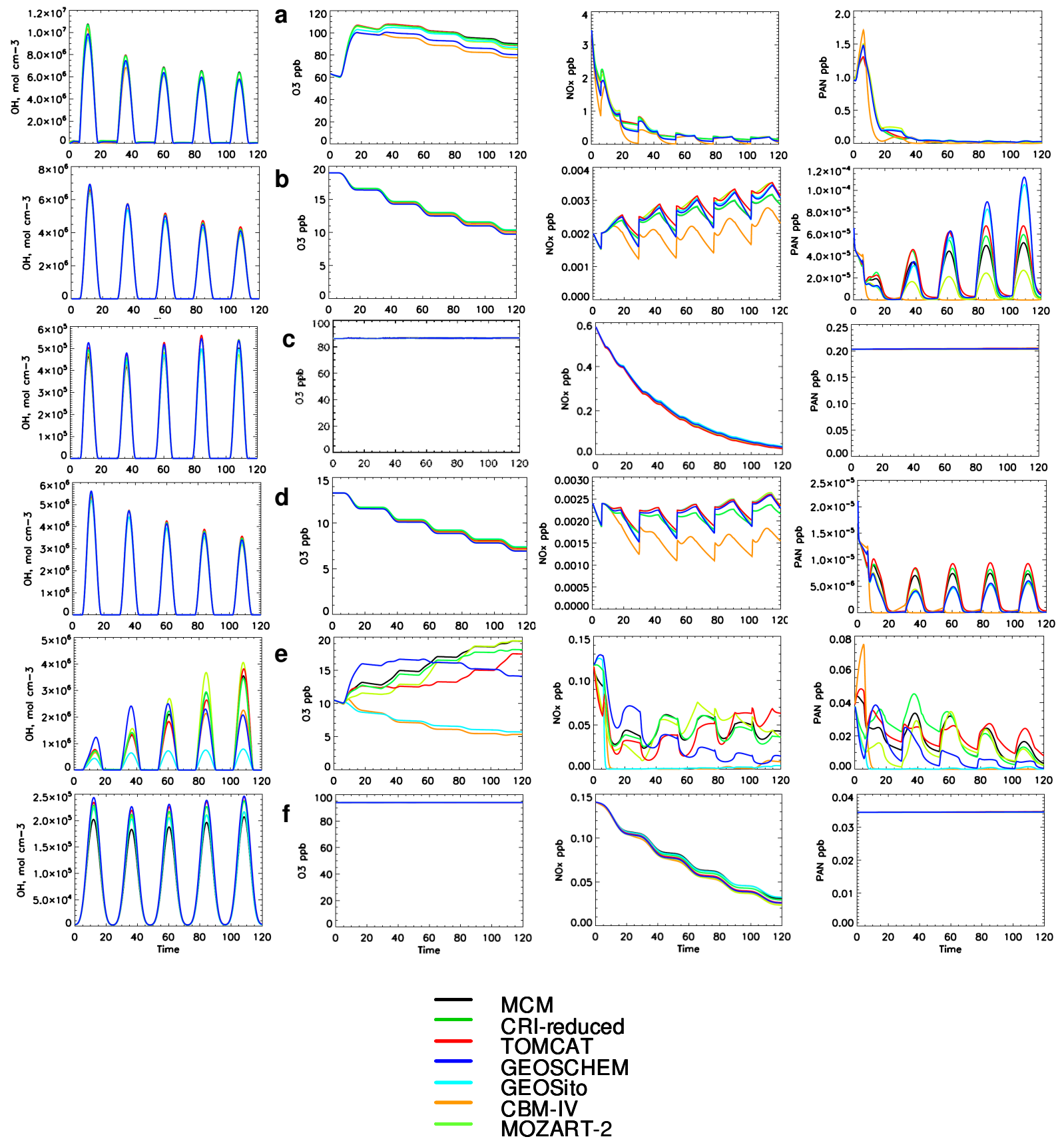

Fig. 3. Full chemistry scheme $120 \mathrm{~h}$ run without $\mathrm{NO}_{\mathrm{x}}^{\text {tot }}$. From left, $\mathrm{OH}, \mathrm{O}_{3}, \mathrm{NO}_{\mathrm{x}}=\mathrm{NO}+\mathrm{NO}_{2}$ and $\mathrm{PAN}$. (a)=industrial, (b)=clean, $(\mathbf{c})=$ cold \&dry, $(\mathbf{d})=$ hot\&wet, $(\mathbf{e})=$ biogenic, $(\mathbf{f})=$ non-biogenic.

\subsection{Full chemistry, without $\mathrm{NO}_{\mathrm{x}}^{\text {tot }}$}

Figure 3 shows the same simulations but with the inclusion of initial conditions for the organic species. Resulting $\mathrm{O}_{3}$ concentrations are given in Table 4. The CRI-reduced scheme emulates the MCM result very well. Differences between the other schemes largely exist in the simulations where $\mathrm{NO}_{\mathrm{x}}$ and VOCs are high. For the "clean" regions simulated (Fig. 3b, $\mathrm{d}$ and $\mathrm{f}$ ) the inclusion of the organic chemistry schemes lead to only small changes in the behaviour of the model. In these regions the concentrations of organic species are low and so it is not surprising that the inclusion of the organics is insignificant on our primary diagnostics $\left(\mathrm{O}_{3}\right.$ and $\left.\mathrm{OH}\right)$. However, one notable difference is the generally lower $\mathrm{NO}_{\mathrm{x}}$ produced by the CBM-IV mechanism with the inclusion of the organics. In Fig. $3 b$ and d, the PAN concentration varies by up to a factor of 5 in the CBM-IV scheme. There is no separate 
acetone species in CBM-IV and the PAN precursor $\mathrm{CH}_{3} \mathrm{CO}_{3}$ is produced from $\mathrm{CH}_{3} \mathrm{CHO}+\mathrm{NO}_{3}$, which is inefficient at low $\mathrm{NO}_{\mathrm{x}}$ concentrations. The two GEOS-CHEM models produce twice the MCM peak PAN concentrations after 5 days (Fig. 3b). At low PAN concentrations significant variations exist between models. PAN is able to transport reactive nitrogen to cleaner regions of the atmosphere, therefore the different abilities of the chemical schemes to calculate PAN lead to concerns that the oxidizing capacities downwind of our box model will vary significantly. These differences reflect both differences in the mechanistic assumptions going into the different models (some models (MCM) include a PAN+OH sink and others do not (GEOS-CHEM)) and differences in the rate constants are assumed.

The biogenic case (Fig. 3e) shows significant variation with some schemes producing $\mathrm{O}_{3}$ and some losing $\mathrm{O}_{3}$. There is also a significant effect on the resulting $\mathrm{OH}$ concentrations. This suggests that there is no real consensus between models as to the impact of isoprene on the chemical system. Much of this debate hinges on the role of isoprene nitrates (Fiore et al., 2005; Ito et al., 2007; von Kuhlmann et al., 2004). Isoprene nitrates are formed through the reaction of $\mathrm{NO}$ with peroxy radicals formed from isoprene oxidation. Degradation of organic nitrates via reaction with $\mathrm{OH}$ returns either $\mathrm{NO}_{\mathrm{x}}$ or $\mathrm{HO}_{\mathrm{x}}$ at the first degradation step, but not both. If $\mathrm{NO}_{\mathrm{x}}$ is returned to the chemical system, organic nitrates can act to transport "reactivity" from the isoprene sources much as PANs do. The net effect being that $\mathrm{O}_{3}$ concentrations can increase. If on the other hand $\mathrm{NO}_{\mathrm{x}}$ is not returned, then overall $\mathrm{O}_{3}$ production is suppressed and $\mathrm{O}_{3}$ loss can occur. Most schemes, with the exception of GEOSito and CBM-IV, will return the stored $\mathrm{NO}_{\mathrm{x}}$.

We test the sensitivity of the $\mathrm{O}_{3}$ concentrations calculated between the two GEOS-CHEM schemes by varying the initial isoprene on a scale between 0.01 and $30 \mathrm{ppb}$. The other inputs to the model were the same as the biogenic scenario inputs given in Table 2. The results (not shown) highlight the uncertainty in the chemistry of isoprene. The GEOSCHEM run showed $\mathrm{O}_{3}$ production from all initial inputs of isoprene. By contrast, the GEOSito scheme shows a distinct regime change from initial $\mathrm{O}_{3}$ production for initial isoprene concentrations less than $2 \mathrm{ppb}$, to $\mathrm{O}_{3}$ loss at initial isoprene concentrations greater than $2 \mathrm{ppb}$. The most marked change in behaviour occurs at isoprene input concentrations between 0.1-1 ppb. The reason for this switch from $\mathrm{O}_{3}$ production to loss in GEOSito is the availability of $\mathrm{NO}_{\mathrm{x}}$. When isoprene concentrations are in excess of $2 \mathrm{ppb}$ the $\mathrm{NO}_{\mathrm{x}}$ is held in the organic nitrates and not released. This test has emphasized the differences in the treatment of isoprene between schemes, and underscores the fact that the chemistry of isoprene in the atmosphere is currently uncertain.

\subsection{Full chemistry, including $\mathrm{NO}_{\mathrm{x}}^{\text {tot }}$}

We repeat the simulations with the constant $\mathrm{NO}_{\mathrm{x}}^{\text {tot }}$ case and show the results in Fig. 4 and Table 4. By keeping the $\mathrm{NO}_{\mathrm{x}}^{\text {tot }}$ concentration constant, one of the dominant feedbacks on the system is removed - that between the organic chemistry and the $\mathrm{NO}_{\mathrm{x}}^{\text {tot }}$ concentrations. The higher $\mathrm{NO}_{\mathrm{x}}^{\text {tot }}$ concentrations together with the lack of surface deposition in the simulations lead to significant $\mathrm{O}_{3}$ production in most cases. In general these results look similar to previous experiments. The largest differences are seen in the biogenic case (Fig. 4e) where the range of $\mathrm{OH}, \mathrm{O}_{3}$ and $\mathrm{NO}_{\mathrm{x}}$ concentrations are highest. The $\mathrm{NO}_{\mathrm{x}}$ concentration in the cold simulations (Fig. $4 \mathrm{c}$ and f) drops slowly as $\mathrm{NO}_{2}$ is converted to $\mathrm{HO}_{2} \mathrm{NO}_{2}$ (we do not initialize concentrations of $\mathrm{HO}_{2} \mathrm{NO}_{2}$ ).

Significant differences between model chemistry schemes are seen during the night. We show the $\mathrm{NO}_{3}$ time series in Fig. 4 instead of PAN because the industrial and biogenic scenarios (Fig. 4a and e) exhibit near constant $\mathrm{NO}_{\mathrm{x}}$ conditions during the day, with substantial conversion at night to $\mathrm{NO}_{3}$ and $\mathrm{N}_{2} \mathrm{O}_{5} . \mathrm{NO}_{3}$ concentrations can vary by factors of $\sim 2$ between models. Some of these differences can be attributed to the different $\mathrm{O}_{3}$ concentrations calculated (which compare the rate of $\mathrm{NO}_{3}$ production through $\mathrm{NO}_{2}+\mathrm{O}_{3}$ ), however other significant differences exist in the treatment of $\mathrm{NO}_{3}+\mathrm{VOC}$ and $\mathrm{NO}_{3}+\mathrm{RO}_{2}$ reactions. These are most significant for the biogenic cases. These differences include the lack of alkenes in some models which thus removes the $\mathrm{NO}_{3}+\mathrm{VOC}$ sink in the model (TOMCAT) or the lack of $\mathrm{NO}_{3}+\mathrm{RO}_{2}$ reaction in some models (GEOS-CHEM). As the simulations are initialised at midnight they may tend to overestimate the differences between the model's nighttime chemistry, however, these differences exist between the schemes and appear significant.

These uncertainties in night time chemistry have a range of implications for night time $\mathrm{NO}_{\mathrm{x}}$ loss, nitrate aerosol production, secondary organic aerosol (SOA) production etc. Recently developed techniques for $\mathrm{NO}_{3}$ and $\mathrm{N}_{2} \mathrm{O}_{5}$ measurement (Brown et al., 2006) will allow enhanced testing of night time chemistry schemes which should yield improvements.

\subsection{Lumped chemistry using TORCH input data}

As described earlier, the conditions derived from the global model underestimate the values likely to occur during a regional scale pollution event due to the spatial and temporal averaging. As computational resources increase, the spatial scale of models is likely to reduce. Thus the concentrations of species that will need to be simulated will increase. To produce simulations at the most polluted levels, observations from the TORCH 2003 summer campaign are used (Lee et al., 2006). The dataset used here represents the mean conditions observed during a regional pollution episode. The campaign was categorized by temperatures up to $312 \mathrm{~K}$ and 

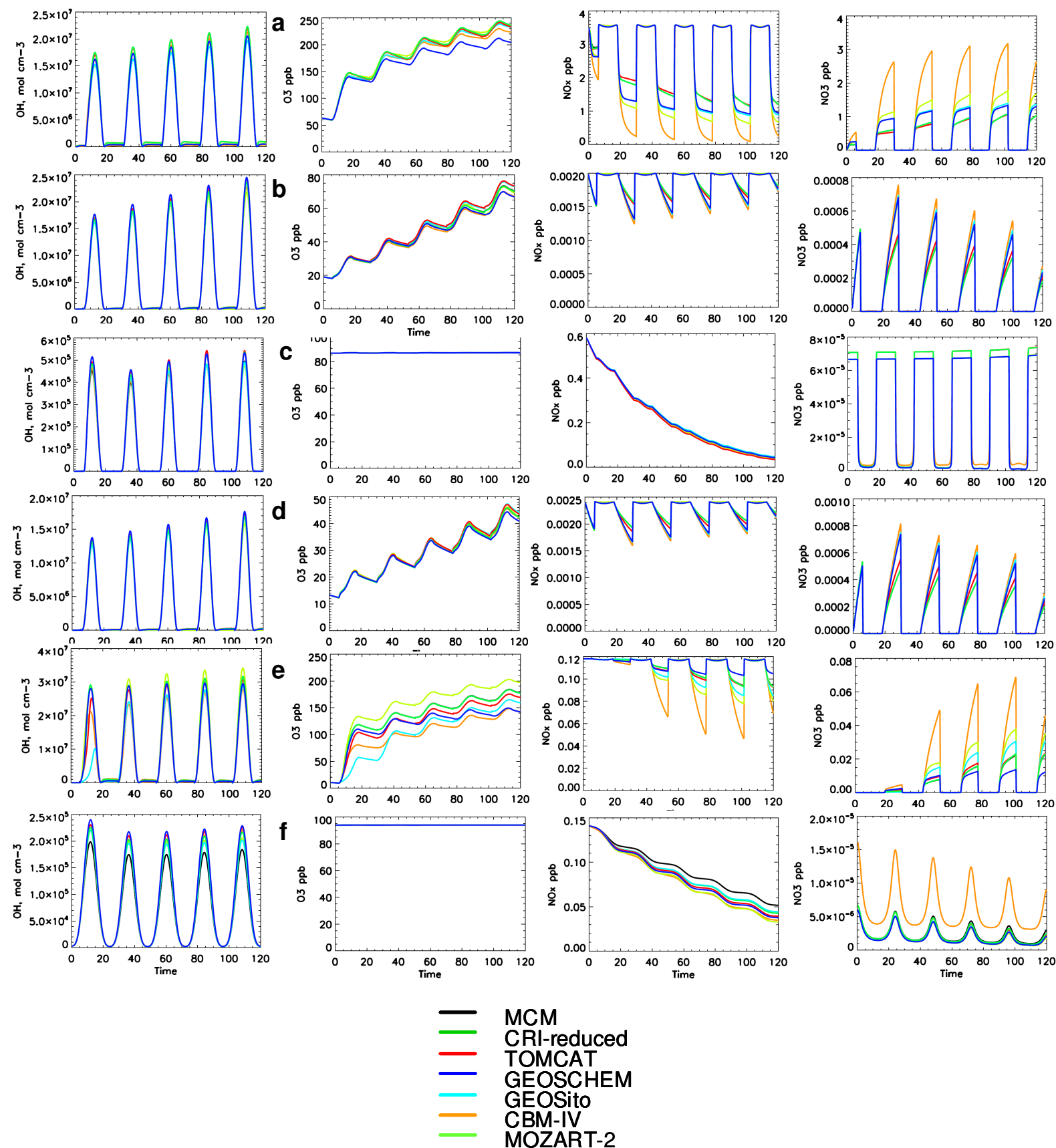

Fig. 4. Full chemistry scheme $120 \mathrm{~h}$ run including the $\mathrm{NO}_{\mathrm{x}}^{\text {tot }}$ case. From left $\mathrm{OH}, \mathrm{O}_{3}, \mathrm{NO}_{\mathrm{x}}=\mathrm{NO}+\mathrm{NO}_{2}$ and $\mathrm{NO}_{3}$. (a)=industrial, (b)=clean, (c) $=$ cold \&dry, (d)=hot\&wet, $(\mathbf{e})=$ biogenic, $(\mathbf{f})=$ non-biogenic.

significant regional scale air pollution. Peak measurements of $\mathrm{O}_{3}$ at the TORCH site reached in excess of $110 \mathrm{ppb}$, and with CO concentrations of $520 \mathrm{ppb}$ (Lee et al., 2006).

Figure 5 and Table 4 show results for the simulation for the average TORCH campaign. We include results for an "inorganic" case (Fig. 5a) using TORCH measurements of $\mathrm{CH}_{4}$, $\mathrm{CO}, \mathrm{NO}_{\mathrm{x}}$ and $\mathrm{O}_{3}$ to investigate the impact of the organic carbon (Fig. 5b). We also show results including the constant
$\mathrm{NO}_{\mathrm{x}}^{\text {tot }}$ case (Fig. 5c). We note that these simulations probably underestimate the impact of the hydrocarbon chemistry on the reduced chemistry schemes. The short lived hydrocarbons are rapidly consumed by oxidants which means that the longer lived species remain and thus perturb the chemistry the most. This favours the skill of the reduced chemistry schemes. 

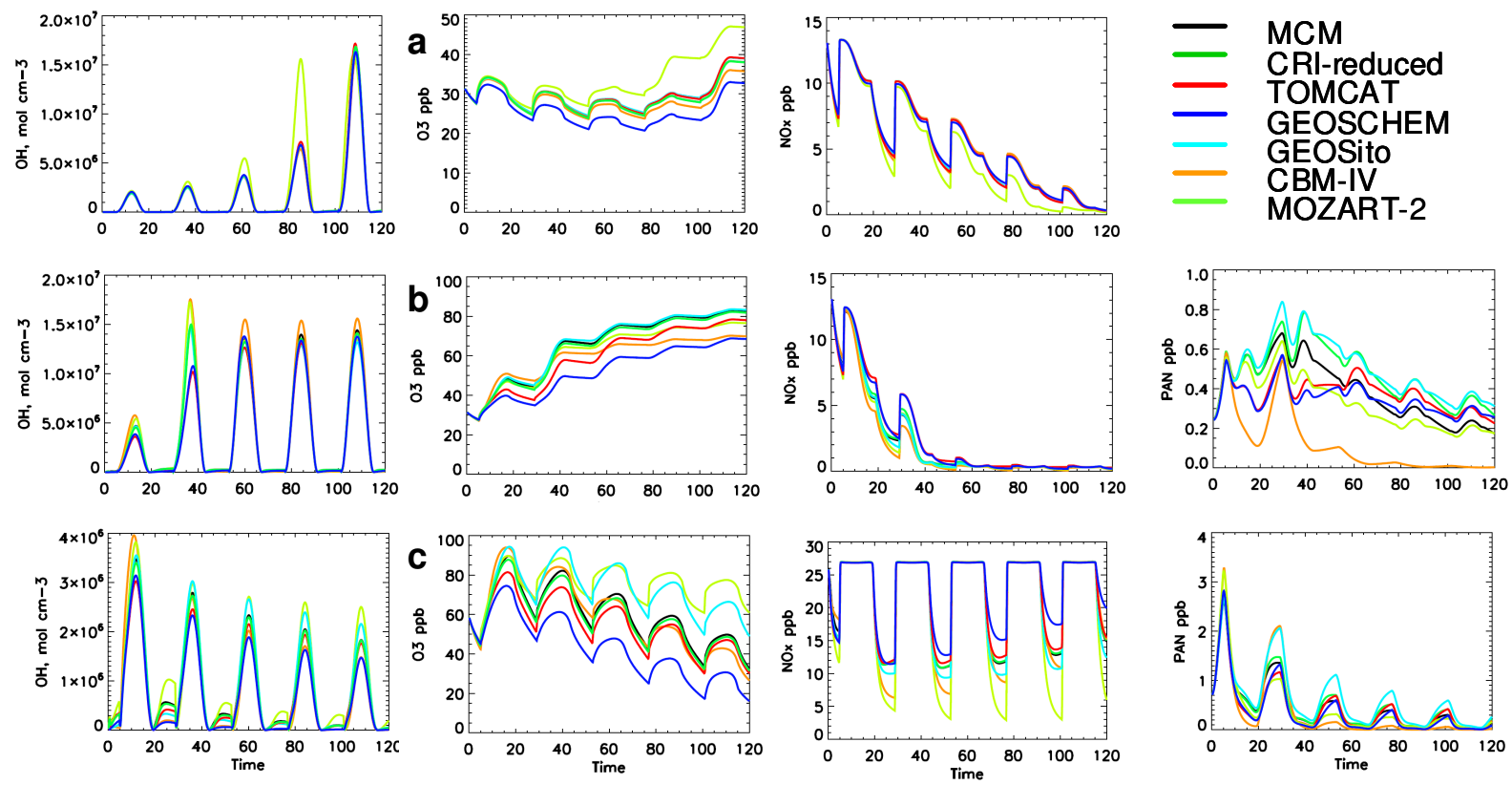

Fig. 5. Average TORCH campaign input data for $120 \mathrm{~h}$ run showing from left $\mathrm{OH}, \mathrm{O}_{3}, \mathrm{NO}_{\mathrm{x}}=\mathrm{NO}+\mathrm{NO}_{2}$ and $\mathrm{PAN}$ (not for inorganic run). (a)=inorganic chemistry only (b)=full chemistry without $\mathrm{NO}_{\mathrm{x}}^{\text {tot }},(\mathbf{c})=$ full chemistry including the $\mathrm{NO}_{\mathrm{x}}^{\text {tot }}$ case.

For all simulations we notice a difference in the night-time chemistry in the $\mathrm{OH}$ and $\mathrm{NO}_{\mathrm{x}}$ profiles, which is due to the treatment of $\mathrm{NO}_{3}$ discussed in Sect. 5.3. Significant differences are also seen in the calculated $\mathrm{O}_{3}$ between schemes, which is more pronounced with the inclusion of the organic scheme simulations due to the higher $\mathrm{NO}_{\mathrm{x}}$ concentrations. The temporal variation in $\mathrm{O}_{3}$ concentrations differ between the inorganic and organic simulations, with a pattern of loss early on for the inorganic test (Fig. 5a), and enhanced production after 75 hours reflecting suppression of $\mathrm{O}_{3}$ production by $\mathrm{NO}_{\mathrm{x}}$ early in the simulation followed by enhanced $\mathrm{O}_{3}$ production later in the simulation as $\mathrm{NO}_{\mathrm{x}}$ decreases. By contrast there is production of $\mathrm{O}_{3}$ from the start in the full chemistry simulations without the constant $\mathrm{NO}_{\mathrm{x}}^{\text {tot }}$ (Fig. 5b). Inclusion of the $\mathrm{NO}_{\mathrm{x}}^{\text {tot }}$ case results in a loss of $\mathrm{O}_{3}$ from the start of the run (Fig. 5c). In this respect the shape of the inorganic TORCH run combines elements from both full chemistry tests. The input concentrations for both full chemistry tests are the same, but inclusion of $\mathrm{NO}_{\mathrm{x}}^{\text {tot }}$ has reduced the overall $\mathrm{O}_{3}$ and $\mathrm{OH}$ concentrations compared with Fig. 5b.

These tests have been designed to investigate how well small chemistry schemes simulate increasingly complex tropospheric input scenarios. Therefore the smaller chemistry schemes have the same concentrations of carbon input, but it has been lumped into smaller molecular weight VOCs (Table 3). Overall the CRI-reduced scheme is an excellent proxy for the MCM. The smaller TOMCAT scheme shows good agreement with the MCM in predicting both $\mathrm{OH}$ and $\mathrm{O}_{3}$ concentrations, even though all the carbon is lumped into the propane species. Such simplifications of the chemistry are necessary if global transport models require a full representation of the composition of the troposphere in future.

\section{Conclusions}

Large explicit schemes of atmospheric chemistry such as the MCM are too complex to be considered for 3-D global chemistry-climate models. However, they can be used as benchmarks against which to compare smaller reduced schemes which are suitable for inclusion. Six chemical schemes have been removed from their parent model environments and run in a simple box model with specific input concentrations. A variety of tests performed here highlight problems, both simple and complex, with the schemes used here. We find several main conclusions:

1. The CRI-reduced scheme contains $4 \%$ of the number of reactions in the MCM, yet has proved to be an excellent MCM surrogate as highlighted by the resulting $\mathrm{O}_{3}$ concentrations from all the simulations in Table 4 . We expect increased use of such reduced schemes in future, where the chemistry can be traced back to larger comprehensive schemes.

2. The gas phase reaction between $\mathrm{N}_{2} \mathrm{O}_{5}$ and $\mathrm{H}_{2} \mathrm{O}$ is included in TOMCAT but not in the other schemes. This leads to significant differences in the concentration of $\mathrm{NO}_{\mathrm{x}}$. This is to some extent a result of our gas-phase only model simulations. If we had included the heterogeneous sink of $\mathrm{N}_{2} \mathrm{O}_{5}$ the simulation would appear less 
sensitive. There appears to be confusion over the existence and rate of this reaction and laboratory studies should be undertaken to evaluate its significance. When this reaction is removed, small differences still exist in the inorganic chemistry schemes of the different models due to reaction rate inconsistencies. This suggests that a future effort should be to reduce some of the differences between model inorganic schemes.

3. PAN concentrations calculated in the full chemistry test without the $\mathrm{NO}_{\mathrm{x}}^{\text {tot }}$ case (Sect. 5.2) varied by up to a factor of 5 under clean conditions (Fig. 3b). The CBM-IV scheme, the smallest tested in this work, excludes acetone and thus has significant problems simulating PAN. Whilst the other mechanisms do include acetone, the rate at which the PAN precursor, $\mathrm{CH}_{3} \mathrm{CO}_{3}$ is produced varies. As PAN is able to transport reactive nitrogen to cleaner regions of the atmosphere, these differences may impact on the oxidizing capacity in remote regions.

4. When organic chemistry is included, the differences between the models increase compared to the inorganic scheme alone. We find that these differences are most pronounced under high biogenic VOC loadings where even the sign of the impact of isoprene on $\mathrm{O}_{3}$ varies between the schemes. We identify the treatment of isoprene derived organic nitrates as the dominant cause of these discrepancies. Given that isoprene emission and chemistry is a critical composition-climate feedback we believe that resolving this issue should be of central importance to future research effort.

5. The night time chemistry also shows considerable differences between the schemes. Significant variations in $\mathrm{NO}_{3}$ concentrations occur in simulations with high VOCs. The $\mathrm{NO}_{3}$ produced varied by a factor of $\sim 2$, and can be attributed to differences in the treatment of $\mathrm{NO}_{3}+\mathrm{VOC}$ and $\mathrm{NO}_{3}+\mathrm{RO}_{2}$ reactions. These variations will impact night time oxidation, nitrate aerosol production and $\mathrm{NO}_{\mathrm{x}}$ concentrations.

In conclusion, we would like to draw attention to the differences that exist within the current generation of chemistry schemes. These differences can impact on the long range transport of species and aerosol production. The simulations performed on the chemistry schemes in this study are extreme. Once embedded within a chemistry transport model, with transport, mixing, emissions and deposition the model sensitivity to the different chemistry will be less. However these simulations highlight the differences that exist between the schemes within the models. This "chemistry uncertainty" is in addition to current model uncertainties due to dynamics, emissions, transport etc. Further laboratory kinetic studies will reduce this uncertainty. Advances in available computer time will soon allow moderately complex schemes such as CRI-reduced, which are based on reductions of explicit schemes, to be included in composition transport and composition climate models. Global model comparisons between simulations using complex chemistries and simpler chemistry will allow for a full evaluation of scheme capabilities.

Acknowledgements. We would like to thank the following people for the provision of chemistry schemes and useful discussions: M. Jenkin, D. Shallcross, L. Watson, O. Wild and P. Young. This work was completed under the NERC QUEST project, grant number NE/C001648/1.

Edited by: V. F. McNeill

\section{References}

Aumont, B., Szopa, S., and Madronich, S.: Modelling the evolution of organic carbon during its gas-phase tropospheric oxidation: development of an explicit model based on a self generating approach, Atmos. Chem. Phys., 5, 2497-2517, 2005, http://www.atmos-chem-phys.net/5/2497/2005/.

Bey, I., Jacob, D. J., Yantosca, R. M., et al.: Global modelling of tropospheric chemistry with assimilated meteorology: model description and evaluation, J. Geophys. Res, 106, 23073-23095, 2001.

Bloss, C., Wagner, V., Jenkin, M. E., Volkamer, R., Bloss, W. J., Lee, J. D., Heard, D. E., Wirtz, K., Martin-Reviejo, M., Rea, G., Wenger, J. C., and Pilling, M. J.: Development of a detailed chemical mechanism (MCMv3.1) for the atmospheric oxidation of aromatic hydrocarbons, Atmos. Chem. Phys., 5, 641-664, 2005, http://www.atmos-chem-phys.net/5/641/2005/.

Brown, S. S., Ryerson, T. B., Wollny, A. G., Brock, A. G., Peltier, R., Sullivan, A. P., Weber, R. J., Dube, W. P., Trainer, M., Meagher, J. F., Fehsenfeld, F. C., and Ravishankara, A. R: Variability in nocturnal nitrogen oxide processing and its role in regional air quality, Science, 311, 67-70, 2006.

Carslaw, N., Creasey, D. J., Heard, D. E., Lewis, A. C., McQuaid, J. B., Pilling, M. J., Monks, P. S., Bandy, B. J., and Penkett, S. A.: Modelling $\mathrm{OH}, \mathrm{HO}_{2}$ and $\mathrm{RO}_{2}$ radicals in the marine boundary layer. 1. Model construction and comparison with field measurements, J. Geophys. Res., 104, 30241-30255, 1999.

Carslaw, N., Creasey, D. J., Harrison, D., Heard, D. E., Hunter, M. C., Jacobs, P. J., Jenkin, M. E., Lee, J. D., Lewis, A. C., Pilling, M. J., Saunders, S. M., and Seakins, P. W.: Modelling OH and $\mathrm{HO}_{2}$ radicals in a forested region of north-western Greece, Atmos. Environ., 35, 4725-4737, 2001.

Chipperfield, M. P., Cariolle, D., Simon, P., Ramaroson, R., and Lary, D. J.: A three dimensional modelling study of trace species in the Arctic lower stratosphere during winter 1989-1990, J. Geosphys. Res., 98, 7199-7218, 1993.

Dentener, F. J. and Crutzen, P. J.: Reaction of $\mathrm{N}_{2} \mathrm{O}_{5}$ on tropospheric aerosols: Impact on the global distributions of $\mathrm{NO}_{\mathrm{x}}, \mathrm{O}_{3}$ and $\mathrm{OH}$, J. Geophys. Res, 98, 7149-7163, 1993.

Derwent, R. G.: Evaluation of a number of chemical mechanisms for their application in models describing the formation of photochemical ozone in Europe, Atmos. Environ. 24A, 2615-2624, 1990.

Emmerson, K. M., Carslaw, N., Carpenter, L. J., Heard, D. E., Lee, J. D., and Pilling, M. J.: Urban Atmospheric Chemistry during the PUMA Campaign, 1: Comparison of Modelled OH 
and $\mathrm{HO}_{2}$ Concentrations with Measurements, J. Atmos. Chem., 52(2), 143-164, 2005.

Emmerson, K. M., Carslaw, N., Carslaw, D. C., Lee, J. D., McFiggans, G., Bloss, W. J., Gravestock, T., Heard, D. E., Hopkins, J., Ingham, T., Pilling, M. J., Smith, S. C., Jacob, M., and Monks, P. S.: Free radical modelling studies during the UK TORCH Campaign in Summer 2003, Atmos. Chem. Phys., 7, 167-181, 2007, http://www.atmos-chem-phys.net/7/167/2007/.

Evans, M. J and Jacob, D. J.: Impact of new laboratory studies of $\mathrm{N}_{2} \mathrm{O}_{5}$ hydrolysis on global model budgets of tropospheric nitrogen oxides, ozone and OH, Geophys. Res. Lett, 32, L09813, doi:10.1029/2005GL022469, 2005.

Fiore, A. M., Horowitz, L. W., Purves, D. W., et al.: Evaluating the contribution of changes in isoprene emissions to surface ozone trends over the eastern United States, J. Geophys, Res, 110, D12303, doi:10.1029/2004JD005485, 2005.

Gao, D., Stockwell, W. R., and Milford, J. B.: Global uncertainty analysis of a regional-scale gas phase chemical mechanism, J. Geophys. Res, 101, 9071-9078, 1996.

Gery, M. W., Whitten, G. Z., Killus, J. P., and Dodge, M. C.: A Photochemical Kinetics Mechanism for Urban and Regional Scale Computer Modeling, J. Geophys. Res., 94, 925-956, 1989.

Hairer, E. and Wanner, G.: Solving Ordinary Differential Equations II Stiff and Differential-Algebraic Problems, Springer-Verlag, Berlin, 1991.

Horowitz, L. W., Walters, S., Mauzerall, D. L., et al.: A global simulation of tropospheric ozone and related tracers: description and evaluation of MOZART-2 version 2, J. Geophys. Res., 108(D24), 4784, doi:10.1029/2002JD002853, 2003.

Houweling, S., Dentener, F., and Lelieveld, J.: The impact of nonmethane hydrocarbon compounds on tropospheric photochemistry, J. Geophys. Res., 103, 10673-10696, 1998.

Ito, A., Sillman, S., and Penner, J. E.: Effects of additional nonmethane volatile organic compounds, organic nitrates, and direct emissions of oxygenated organic species on global tropospheric chemistry, J. Geophys. Res., 112, D06309, doi:10.1029/2005JD006556, 2007.

IPCC: Climate Change 2007: The Physical Science Basis, in: Contribution of Working Group I to the Fourth Assessment Report of the Intergovernmental Panel on Climate Change, edited by: Solomon, S., Qin, D., Manning, M., Chen, Z., Marquis, M., Averyt, K. B., Tignor, M., and Miller, H. L., Cambridge University Press, Cambridge, United Kingdom and New York, NY, USA, 996 pp., 2007.

IUPAC: Summary of evaluated kinetic and photochemical data for atmospheric chemistry, IUPAC subcommittee for Gas Kinetic Data Evaluation, 2001.

Jenkin, M. E., Saunders, S. M., Derwent, R. G., and Pilling, M. J.: Development of a reduced speciated VOC degradation mechanism for use in ozone models, Atmos. Environ., 36, 4725-4734, 2002.

Jenkin, M. E., Saunders, S. M., Wagner, V., and Pilling, M. J.: Protocol for the development of the Master Chemical Mechanism, MCM v3 (Part B): tropospheric degradation of aromatic volatile organic compounds, Atmos. Chem. Phys., 3, 181-193, 2003, http://www.atmos-chem-phys.net/3/181/2003/.

Jenkin, M. E and Hayman, G. D.: Photochemical ozone creation potentials for oxygenated volatile organic compounds: sensitivity to variations in kinetic and mechanistic parameters, Atmos.
Environ., 33(8), 1275-1293, 1999.

Jenkin, M. E., Watson, L. A., Utembe, S. R., and Shallcross, D. E.: A Common Representative Intermediates (CRI) mechanism for VOC degradation - Part 1: Gas phase mechanism development, Atmos. Environ., 42, 7185-7195, doi:10.1016/j.atmosenv2008.07.028, 2008.

JPL: Chemical kinetics and photochemical data for use in atmospheric studies, Evaluation number 15, California Institute of Technology, Pasadena, CA, 2006.

Law, K. S., Plantevin, P.-H., Shallcross, D. E., Rogers, H. L., Pyle, J. A., Grouhel, C., Thouret, V., and Marenco, A.: Evaluation of modeled $\mathrm{O}_{3}$ using Measurements of Ozone by Airbus In-Service Aircraft (MOZAIC) data, J. Geophys. Res., 103, 25721-25737, 1998.

Lee, J. D., Lewis, A. C., Monks, P. S., et al.: Ozone photochemistry and elevated isoprene during the UK heatwave of August 2003, Atmos. Environ., 40, 7598-7613, 2006.

Logan, J. A., Prather, M. J., Wofsy, S. C., and McElroy, M. B.: Tropospheric Chemistry: A Global Perspective, J. Geophys. Res. 86(C8), 7210-7254, 1981.

O'Connor, F. M., Law, K. S., Pyle, J. A., Barjat, H., Brough, N., Dewey, K., Green, T., Kent, J., and Phillips, G.: Tropospheric ozone budget: regional and global calculations, Atmos. Chem. Phys. Discuss., 4, 991-1036, 2004, http://www.atmos-chem-phys-discuss.net/4/991/2004/.

Olsen, J., Prather, M., Berntsen, T., et al.: Results from the Intergovernmental Panel on Climatic Change Photochemical Model Intercomparison (Photocomp), J. Geophys. Res., 102, 5979-5991, 1997.

Pöschl, U., von Kuhlmann, R., Poisson, N., and Crutzen, P. J.: Development and intercomparison of condensed isoprene oxidation mechanisms for global atmospheric modelling, J. Atmos. Chem., 37, 29-52, 2000.

Sandu, A. and Sander, R.: Technical note: Simulating chemical systems in Fortran90 and Matlab with the Kinetic PreProcessor KPP-2.1, Atmos. Chem. Phys., 6, 187-195, 2006, http://www.atmos-chem-phys.net/6/187/2006/.

Saunders, S. M., Jenkin, M. E., Derwent, R. G., and Pilling, M J.: Protocol for the development of the Master Chemical Mechanism, MCM v3 (Part A): tropospheric degradation of nonaromatic volatile organic compounds, Atmos. Chem. Phys., 3, 161-180, 2003, http://www.atmos-chem-phys.net/3/161/2003/.

Shindell, D. T., Faluvegi, G., and Bell, N.: Preindustrial-to-presentday radiative forcing by tropospheric ozone from improved simulations with the GISS chemistry-climate GCM, Atmos. Chem. Phys., 3, 1675-1702, 2003,

http://www.atmos-chem-phys.net/3/1675/2003/.

Sommariva, R., Haggerstone, A.-L., Carpenter, L. J., Carslaw, N., Creasey, D. J., Heard, D. E., Lee, J. D., Lewis, A. C., Pilling, M. J., and Zádor, J.: $\mathrm{OH}$ and $\mathrm{HO}_{2}$ chemistry in clean marine air during SOAPEX-2, Atmos. Chem. Phys., 4, 839-856, 2004, http://www.atmos-chem-phys.net/4/839/2004/.

Stockwell, D. Z. and Chipperfield, M. J.: A tropospheric chemical transport model: development and validation of the model transport schemes, Q. J. Roy. Meteor. Soc., 125, 1747-1783, 1999.

Szopa, S., Aumont, B., and Madronich, S.: Assessment of the reduction methods used to develop chemical schemes: building of a new chemical scheme for VOC oxidation suited to threedimensional multiscale $\mathrm{HO}_{\mathrm{x}}-\mathrm{NO}_{\mathrm{x}}-\mathrm{VOC}$ chemistry simulations, 
Atmos. Chem. Phys., 5, 2519-2538, 2005,

http://www.atmos-chem-phys.net/5/2519/2005/.

von Kuhlmann, R., Lawrence, R. M., Pöschl, U., and Crutzen, P. J.: Sensitivities in global scale modelling of isoprene, Atmos. Chem. Phys, 4, 1-17, 2004.

Watson, L. A., Shallcross, D. E., Utembe, S. R., and Jenkin, M. E.: A Common Representative Intermediates (CRI) mechanism for VOC degradation - Part 2: Gas phase mechanism reduction, Atmos. Environ., 42, 7196-7204, doi:10.1016/j.atmosenv.2008.07.034, 2008.
Wu, S., Mickley, L. J., Jacob, D. J., et al.: Why are there large differences between models in global budgets of tropospheric ozone?, J. Geophys. Res., 112, D05302, doi:10.1029/2006JD007801, 2007.

Zaveri, R. A. and Peters, L. K.: A new lumped structure photochemical mechanism for large-scale applications, J. Geophys. Res, 104, 30387-30415, 1999. 